\title{
A Critical Look at Sustainable Development in the Canadian North FRANK DUERDEN ${ }^{1}$
}

\author{
(Received 31 October 1989; accepted in revised form 15 October 1991)
}

\begin{abstract}
The notion of sustainable development has considerable appeal in northern Canada, a reflection of traditional practices of indigenous populations and the region's experiences with the encroachment of industrial society. The lexicon of "sustainable development" has made the identification of appropriate economic activities a central issue. There is no standard approach to this problem although Weeden (1989) produced a useful framework for evaluation. Analysis of the evolution of the economic geography of the North provides some insights into both the current emphasis on the role of communities in sustainable development strategies and the origin of candidate activities. Review of possible candidate activities suggests that there is perhaps a tendency to confuse renewal with sustainability and that the appropriateness of activities may be called into doubt when viewed from the standpoint of relative energy consumption and global context. Sustenance harvesting is seen as perhaps the most viable sustainable activity, although some assessments of its value may be overstated. Non-renewable resource exploitation is a particular problem, yet the extraction of some non-renewable resources may contribute to a global goal of sustainability. A prerequisite for the development of a rational approach to sustainability lies in establishing the nature of the reciprocal relationship between urban centres and the northern periphery.
\end{abstract}

Key words: sustainable, development, energy, harvesting, indigenous, resource

RÉSUMÉ. Le concept de développement durable jouit d'une grande popularité dans le Canada septentrional, ce qui reflète les pratiques traditionnelles des populations autochtones et l'expérience qu'a la région de l'empiétement de la société industrielle. Le vocabulaire du développement durable a fait de l'identification des activités économiques appropriées une question centrale. Il n'existe pas d'approche standard à ce problème bien que Weeden (1989) ait produit un cadre utile d'évaluation. Une analyse de l'évolution de la géographie économique du Nord offre un éclairage à la fois sur l'importance actuellement mise sur le rôle des collectivités dans les stratégies de développement durable et sur l'origine d'activités potentielles. Une étude de ces dernières suggère qu'on a peut-être tendance à confondre le renouvellement avec le développement durable et que la pertinence des activités pourrait être remise en question si on l'examinait du point de vue de la consommation relative d'énergie et du contexte global. Le prélèvement de subsistance est perçu comme l'activité durable peut-être la plus viable, bien que certains jugements sur sa valeur puissent être exagérés. L'exploitation des ressources non renouvelables constitue un problème particulier, encore que l'exploitation de certaines de ces ressources pourrait contribuer à un objectif global de développement durable. Une condition préalable à l'élaboration d'une approche rationnelle au développement durable consiste à déterminer le caractère de la relation réciproque entre les centres urbains et la périphérie nordique.

Mots clés: durable, développement, énergie, prélèvement, autochtone, ressource

Traduit pour le journal par Nésida Loyer.

\section{INTRODUCTION}

There are a number of reasons for interest in the possibilities for sustainable development in the Canadian North. The most obvious is the symbolic value of the notion itself - the mantra "think globally, act locally" (World Commission on Environment and Development, 1987) is an easily articulated basis for empowerment and action for communities and populations that have felt the adverse environmental and social impacts of resource exploitation. The tendency to imbue North American indigenous populations with the characteristics of a society that is environmentally conscious and caring is not new (Martin, 1978), and the assertion that indigenous populations are role models for the sustainable development movement is a logical extension of this view. The obvious relationship between the notion of an environmentally sensitive society and sustainable development has already generated a number of papers promoting the merits of northern indigenous populations as practitioners of sustainability (Kassi, 1987; Usher, 1987; Mulvihill and Jacobs, 1991).

The pragmatic basis for consideration of the possibility of sustainable development in the North arises from the conflict between expanding populations and narrow ecosystems and from pressure placed on northern communities and the environment by increasing integration into the global economy. Northern communities are faced with the challenge of supporting increasing populations, promoting community health in the broadest sense and providing meaningful, dignified employment. The means identified to bring about such development include community involvement in decision making (Kassi, 1987), promotion of small-scale and often labour-intensive activities (Pell and Wismer, 1987), promotion of ecologically sound activities (Rees, 1988; Weeden, 1985) and local investment of non-renewable resource revenues (Robinson and Pretes, 1988).

Defined simply, sustainable development means activity that is sensitive to the environmental context and takes into account the well-being of future generations. Weeden (1989), borrowing from Firey (1966), provided a catholic definition of sustainable development for the North, arguing that a sustainable activity is one that is economically feasible, environmentally sound and socially acceptable. Naess (1988) encapsulates the perspective of the deep ecology movement that sustainable development should avoid speciesism and consider long-term needs and place priority on the global context.

This paper reviews suggested approaches to sustainable development in the North. It proceeds by outlining the manner in which evolution of the North's economy has conditioned both the need and the possibilities for sustainable development. It then examines the role of communities in sustainable development, moving to look at the possibilities in various land-use sectors, and concludes by critically examining the various approaches in both local and global contexts.

\section{THE ECONOMIC LANDSCAPE OF THE NORTH}

The economic landscape of the North is the immediate spatial context of the sustainable development debate. While this 
landscape defines the range of possible sustainable activities, the conflicts and changes that accompanied its evolution give the notion of community empowerment that is assumed to accompany sustainable development great appeal.

Market economies and non-renewable resource activity introduced to the North over the past 200 years were accompanied by intractably linked social, technological and demographic changes. The introduction of an exchange economy incorporating distant industrial societies meant that products from the land could generate imported material goods along with the traditional requirements for survival, and the fervour with which fur-bearing animals and marine mammals were slaughtered created the first market-generated environmental stress in the North (Ross, 1981; Ray, 1984; Martin, 1978).

As the demands of industrial societies grew, so, in some regions, mining superseded renewable resource harvesting in importance. Mining is a patently unsustainable activity and often detracts from the quality of other land uses. In the North its ascendancy was marked by local displacement of Native subsistence harvesting, either through direct environmental degradation or displacement due to population pressures (Cruikshank, 1974; Dimitrov and Weinstein, 1984; McCandless, 1985). The legitimacy and dominance of mining, and more recently energy extraction, in the North was institutionalized through legislation such as the Yukon Placer Act and in recent times the Canada Oil and Gas Act, designed to encourage or facilitate extraction, essentially giving it precedence over other land uses.

The manner in which industrially oriented activity and its associated populations brought increased pressure on the land and transformed attitudes towards resources and consumption is generally well known. What is not perhaps so clearly acknowledged is the extent to which early industrial society approached self-sufficiency, with trade goods as a veneer over strong dependency on the land for food and energy. The extreme classic example of this is the Klondike Gold Rush. Although essentially urban in character and accompanied by all the trappings of late Victorian industrial technology, the early 20th-century population of the Dawson region depended heavily on local resources. Building materials and fuel were obtained from the local region, and it is estimated that 12 million board feet of timber were utilized in 1898 just to build Dawson City (Heartwell, 1988). Several farms emerged providing the basic vegetable requirements of the population (Robinson, 1945), and McCandless (1985) has estimated that in the early 1900s the Dawson population obtained at least $33 \%$ of its meat supply from the land. This approach towards self-sufficiency was unsustainable. The quest for fuel ranged over several hundred square kilometres, resulting in major deforestation, with attendant biophysical impacts. Up to 1200 moose and 4600 caribou were harvested in 1904 alone in the area surrounding Dawson City, probably with profound ecological consequences (McCandless, 1985).

The significance of late-19th-century developments in the Yukon lies in the fact that the types of activities introduced and the conflicts they generated characterize contemporary debates about sustainability in the North. Agriculture and forestry persist in the North and are promoted because of their possible substitution effects in local economies (Government of Yukon, 1986; Hodge, 1982). Non-renewable resource extraction continues to have deleterious impacts on Native food harvesting, and the re-assertion of local and traditional control over resource management is seen as the key to sustainability (Usher, 1987).
The Klondike Gold Rush was a unique, spectacular and short-lived event, and it was not until after the Second World War that the increasing tempo of industrialization in the North provided a basis for intermittent debate regarding desirable futures for the region. It was with the energy crisis of the early 1970s and its attendant plethora of megaproject proposals that this debate intensified. The duality of the northern economy was brought into sharp focus, with the distant energy needs of the continent's urban industrial infrastructure pitted against concerns about local economies and well-being. New impetus was given to the transformation of northern economies, and the desire to remove impediments to industrial development combined with a landmark legal decision (Calder et al. vs. Attorney General of British Columbia) resulted in increased emphasis on the resolution of Native claims (Task Force to Review Comprehensive Claims Policy, 1985).

\section{SOCIAL IMPACT OF CHANGE}

The impact of industrial incursions on Native society is well documented. As the supply of consumer goods increased and new forms of technology were introduced to the North, a dichotomy developed between a societal structure traditionally geared towards low-technology harvesting and dependent on locally obtained resources and (thanks to trucks, snowmobiles and outboard motors) a new ability to harvest effectively with (relative to the past) less expenditure of time or effort. Over the past few years satellite dishes and VCRs plugging isolated communities into the outside world have introduced a plethora of urban-based life-style role models and associated exhortations to consume, further serving to strengthen the hold of industrial society. The resultant structure of Native economic life was best characterized by Brody (1981) as a mix of harvesting, part-time employment and transfer payments.

Societal change and economic shifts have been accompanied by demographic trends, which are an important back-drop to any discussion of sustainability. The population dynamics of contemporary indigenous and non-indigenous groups contrast sharply. Among indigenous populations there is a high birthrate, accompanied by a tendency to migrate towards major urban centres in the North on either a permanent or temporary basis. This migration rate is not high enough to offset the impact of the high birthrate in small communities, especially in the Eastern Arctic. The population of Baffin Region increased by $20 \%$ between 1981 and 1986 , and some $27 \%$ of the population is below the age of nine - comparative figures for Canada are $4 \%$ and $14 \%$ respectively (Statistics Canada, 1987). Increases in indigenous populations in areas with a narrow ecosystem place pressures on both local sources of food supply and waste disposal systems. Constant non-Native population levels are largely illusory and are maintained by high population turnover rates. In reality a substantial portion of the non-Native population stays in the North for only short periods of time (Duerden, 1983). Because of its transient nature, much of the non-indigenous population may have no vested interest in maintaining the quality of the local environment.

\section{SUSTAINABLE DEVELOPMENT — THE COMMUNITY PERSPECTIVE}

A major emphasis by proponents of sustainable development in the North is that it should take place at the community level, with community values taking precedence over other factors in determining appropriate courses of action. This 
emphasis is a reaction to the types of problems identified that emanate from activities and values drawn from distant regions and is reflected in the range of countervailing considerations that various authors stress should be incorporated into sustainable development - ecologically sensitive and appropriate development (Rees, 1988; Weeden, 1989), emphasis on the role of indigenous knowledge (Usher, 1987), promotion of sunrise industries utilizing local skills (Pell and Wismer, 1987), subsidy of traditional harvesting activity (Quigley and McBride, 1987), community empowerment (Kassi, 1987) and restructuring of north-south interdependence (Mulvihill and Jacobs, 1991).

Usher (1987) encapsulates the arguments in favour of community-based approaches towards sustainability by arguing that by returning control of resource decision making to the community level, the presence of social constraints and collective community interest avoids the deterioration of common property resources. Hardin (1968) characterized this "tragedy of the commons" as having its roots in the lack of collective interest in maintaining the quality of resources, a tragedy that in the case of land was ameliorated through private as opposed to collective ownership. Usher's view is the antithesis of this approach, arguing that the collective interest manifest in the contemporary and traditional land management and harvesting practices of indigenous populations is an appropriate basis for the promotion of sustainable development in the North. Because of their vested interest in the quality of the renewable resource base as a source of food and a cornerstone of cultural well-being, Native populations will manage land in such a way that it would not become degraded.

Essentially Usher's (1987) argument has two components: First, distant control and distant interest exacerbate the tragedy of the commons. Second, in the past culturally based land management practices of native groups reflective of collective interest in sustenance and well-being resulted in long-term maintenance of a healthy resource base. There is ample evidence (see, for example, Brody, 1981, or the background to the Dene, Inuvialuit or Yukon land claims) that attempts to assert indigenous land management interests have been impeded by the manner in which effective control often lies in the hands of distant and often faceless interests, such as corporations or government.

There is some controversy regarding the notion of indigenous populations as conservationists or beneficial resource managers. Berkes (1987) clearly illustrated the manner in which culturally based management practices of the Chisabi Cree of James Bay have continued to maintain the health of the Native food fishery; on the other hand, Brightman (1987) argues that Algonquins had no conscious notion of conservation. People-land relationships, certainly in less isolated areas, have been transformed radically in the last 200 years, with explanations ranging from Martin's (1978) argument that the mystical basis for conservation was shattered by events accompanying proto-contact to Farb's (1968) economically deterministic view that indigenous attitudes towards land were radically transformed with the realization that it had an exchange value rather than a use value. There is little dispute that transformations of relationships with land started with the fur trade but alienation from traditional ways was subsequently exacerbated (as Usher [1987] acknowledges) by wage employment, increased accessibility to consumer goods, government relocation and settlement rationalization programs and dramatic changes in communications. Wolfe and Walker (1987) provide quantitative evidence for the adverse impact of such changes on the volume of country food harvests in Alaska.

\section{NATIVE HARVESTING AS A SUSTAINABLE ACTIVITY?}

Maintenance or enhancement of native harvests is a function of the interplay among population levels, the biophysical resource base and competition from other forms of land use. Fuller and Hubert (1981) examined the prospects for increased sustainable yields in the Northwest Territories (N.W.T.) and concluded that, given contemporary population trends, the projected population increase to the end of the century would only be supported at present participation rates. Although Fuller and Hubert may be unduly pessimistic, it does point to the eventual inability of the country food base to support increasing populations. There would be considerable costs associated with maintaining or improving on contemporary levels of activity, and resources would have to be harvested over a wide area, incurring increased transport energy costs. Fuller and Hubert developed a scenario in which every major river in the N.W.T. would have to be harvested in order to provide increased sustainable yields. Thus population pressures mean environmental degradation or increased energy costs, or both.

The imputed value of country food harvests has been used extensively to depict the value of native harvesting in conventional economic terms (Brody, 1981; Dimitrov and Weinstein, 1984; Rushforth, 1977; Stager, 1974; Usher, 1971, 1976). At one level such studies make impressive reading. In Sanikiluaq, for example, $57 \%$ of community income was in the form of imputed value of country food (Quigley and McBride, 1987). Valued at some $\$ 2$ million for a community of 435 , this indicates a very healthy local harvesting economy. Brody (1981) calculated that for East Moberly approximately 33\% of community income was in the form of replacement value harvest from the land. In the Yukon, Dimitrov and Weinstein (1984) valued country food harvests for Ross River at in excess of $50 \%$ of community income; for the community of Teslin the figure was $25 \%$ (Duerden, 1986). However these figures can also be interpreted as indicative of the weakness of other sectors of the community economy and the obvious limitations on native harvesting as an income generator. Communities where the proportion of expenditure on food greatly exceeds the average Canadian family expenditure on neccessities are in reality cash poor; at the same time there is an obvious upper limit on the value of country food harvests - self-sufficiency. The economically precarious nature of Native harvesting is further highlighted by the observations of a number of proponents of Native harvesting that communities depend on a variety of transfer payments to cover the capital costs associated with wildlife harvesting (Brody, 1981; Duerden, 1986; Fuller and McTiernan, 1987; Staples and Usher, 1988; Quigley and McBride, 1987).

Thus it is not too difficult to portray Native harvesting as a barely viable pursuit, clearly falling outside Weeden's definition of sustainable development. The environmental basis is precarious as populations expand, and the economic viability is in doubt. The conventional economic approach, however, ignores the manner in which harvesting and culture are interwoven, virtually synonymous activities and also ignores the various costs associated with its collapse. Community cohesion, community stability, development and maintenance of selfesteem with attendant diminution of social problems are seen to flow from enhancement of country food harvests and the assertion of the primacy of traditional land use. Ultimately the maintenance of high harvest levels in indigenous communities is most legitimately seen not as an economically sustainable 
activity from a conventional standpoint but rather a community and cultural sustaining activity promoting community well-being. This argument can also be cast in brutally positivistic terms; it is less costly to sustain such harvesting activities than it is to bear the costs, both tangible (unemployment benefits, welfare, hospitalization) and intangible (social justice, human waste) of societal breakdown.

Conventional economic arguments also ignore various nonmonetary costs associated with surrogates for country food, and it is with these costs that the real essence of the sustainable development debate lies. Country food is supported by the biosphere and the local ecosystem, and the energy exchanges involved are natural; probable surrogates (for example, beef) involve the utilization of fossil fuels at various stages of the production process, and their production involves net energy deficits. Lovins et al. (1984) estimate that in the United States almost ten calories of energy are required for production, processing, distribution and preparation for each calorie of food consumed. In the North additional energy is required for importing foodstuffs over vast distances. The major energy use related to Native harvesting is for bush or river transportation, and the upper limits on its sustainability would be that point where pressure on the land brought about diminishing returns and hor energy costs per unit exceeded those for imported food. Both are obviously strongly related insomuch as harvesting over larger areas would be a probable response to local resource depletion. Thus in terms of community well-being, relative energy consumption and historical compatibility with the environment, native harvesting appears as an eminently sustainable activity. However, it must be recognized that population growth threatens to place strong pressure on the physical resource base and thus the long-term quality of the environment.

\section{NON-TRADITIONAL APPROACHES TO SUSTAINABLE DEVELOPMENT}

Because of its symbiotic relationship to cultural values, enhancement of country food harvests is perhaps the most widely discussed approach to sustainable development. Other possible renewable resource endeavours include greater reliance on fuel wood, expansion of northern agriculture and non-consumptive tourism.

Small native communities south of the tree line are or can be close to self-sufficient in terms of wood-based energy, and Hodge (1982) made the case that there is potential for increased sustainable reliance on wood fuel at an even larger scale. It was calculated that in the Yukon an average household requires twelve cords of wood per year, and that 60 acres of land are required to harvest this on a sustainable basis. The city of Whitehorse would require 270000 acres of trees to provide wood-based energy for its population on a sustainable basis. Chipping and increased insulation may result in a reduction of acreage required by a factor of 3.5 , and there are 80000 acres of woodland in the Whitehorse region. The impact of these approaches in promoting sustainability is unknown, although it can be conjectured that the ecological impact of large-scale firewood harvesting could be profound. Given regeneration periods in the North, it is questionable whether harvesting of northern forests can really be considered to be a renewable resource activity, while large-scale utilization of firewood may have a deleterious effect on air quality in north- ern communities. The Riverdale subdivision of Whitehorse recorded the most intense domestically generated air pollution in Canada (Environment Canada, pers. comm. 1986).

Agriculture has been a persistent, if precarious, activity in parts of the middle and near North since the turn of the century. Increased agricultural viability is of interest in the N.W.T. (Resource Management Consultants, 1985), while there is sufficient arable land for the Yukon to be self-sufficient in some agricultural commodities (Redpath, 1979). A growing local market as populations expand, the local economic advantages of substituting for imported produce and the alleged superiority of local produce are arguments used by lobbyists who believe that northern agriculture is sustainable.

Increased agricultural activity would be manifest in increased hothouse operations, extension of arable land and greater emphasis on cattle farming. Ecological modifications would be attendant on land clearance, and (if experience in southern Canada is replicated) attitudes towards "wild animals" would probably become more hostile as predation increased. Land-use conflicts between agriculture and wildlife harvesting and commercial and non-commercial wildlife harvesting may ensue. At the time of the Klondike Gold Rush farming in marginal areas was made profitable by the presence of a relatively large population and isolation from the major agricultural areas of North America (Robinson, 1945); today in both time space and cost space the North is a lot closer to the major producing areas. Irrigation, hothouses and improvement of marginal soils are all major costs of northern agricultural operations. In the North these costs have usually been be measured in conventional monetary terms (Alaskan Agricultural Action Group, 1983), but a more appropriate approach may be to measure energy consumption in northern agriculture relative to energy consumption associated with using the land for country food or to energy invested in imported agricultural produce.

There are no direct data regarding energy consumption by agriculture in the N.W.T., but the author's manipulation of data depicting energy consumption in the agricultural sector and value of agricultural production for eco-regions of the Canadian provinces (Statistics Canada, 1986) reveals that the energy required to produce one dollar's worth of output per hectare increases considerably with nordicity. The highest energy input requirement was in the Boreal Plain eco-region (northern Saskatchewan, northern Manitoba), followed by the Cordillera and the Boreal Shield (northern Ontario). The Boreal Plain required about three times the energy input of agriculture on the Pacific coast, about twice as much as southern Ontario and about $50 \%$ more than on the prairies.

Non-consumptive tourism has many of the characteristics nominally associated with sustainable development. It can be characterized as a sunrise industry most compatible with the seasonal cycle of indigenous life and has the greatest potential to utilize indigenous land-related skills. It often involves small-scale enterprises and a range of services (food, accommodation, guiding) and thus has the greatest potential for putting money into circulation in communities. Because of physical constraints, many communities north of the tree line have limited municipal services, and development that would not aggravate environmental stress would perhaps only occur if much of the tourism infrastructure were insulated from the immediate physical environment. In an extreme version of this schema tourism would perhaps constitute the basic sector of the economy, tourists would be brought from distant regions, increasing volumes of food would be imported and, given the 
inadequacy of community sanitation programs, waste exported. Transporting tourists from urban centres to distant locations is energy consumptive - the promotion of tourism may optimize sustainability in small communities but detract from a global objective of sustainability.

\section{THE ROLE OF THE NON-RENEWABLE RESOURCE SECTOR}

Thus far this paper has dealt with questions regarding the renewable resource sector because renewal is a key element of sustainable development. Exploitation of non-renewable resources is the strongest link between the North and the global economy, and for many outsiders mining is synonymous with "northern development." Mining is an activity that is by nature unsustainable and that through negative impacts on other land uses (for example native harvesting) may detract from the sustainability of other activities.

However, while it is obvious that mining is not compatible with sustainable development, it is also highly unlikely that it will disappear from the northern landscape. The only ways in which its adverse impacts could be ameliorated would be if it did not have priority over other uses and if the northern economy were structured in such a way that more of its economic benefits were channelled to enhance environmentally compatible economic activities. This approach has been advocated by Robinson and Pretes (1988). They suggest the use of trust funds generated through non-renewable resource revenue to enhance community-based renewable resource activities. Asch (1982) had recognized the link between non-renewable resource revenues and funding for traditional renewable resource harvesting, arguing that taxation of mining ventures should generate a capital base for a culturally appropriate renewable resource economy. However, he also expressed concerns that this approach may make the capital base for harvesting dependent on the pace of industrial activity.

If the scale is shifted from a discussion of sustainable development in the North to sustainable development and the North, moving from the local scale to the continental or global scale, the perspective changes somewhat. Natural gas extraction, for example, may have deleterious effects on the northern environment and thus on the prospects for sustainability at the local and regional levels. Compared with other forms of energy, natural gas is relatively clean (Canadian Gas Research Institute, 1989). Its utilization as a surrogate for other fossil fuel sources of energy in urban areas, along with energy conservation measures, may go some way towards improving the quality of the physical environment for large populations and thus contribute towards a global goal of sustainability.

\section{DISCUSSION}

From the foregoing it is obvious that there are considerable difficulties in nailing down the practical dimensions of sustainable development in the the North and moving beyond the important symbolic value of the notion to identify appropriate approaches. At the outset there are a number of approaches that from time to time have been associated with the notion of sustainability. These include sustainable self-sufficiency (precontact society), strong dependence on local resources (initially characterized by the Klondike era and now by promotion of substitution effects in the northern economy), and sustaining development (the maintenance of community-based renew- able resource activities in order to promote economic/social well-being).

A major element missing from the debate on sustainable development for the North is the emergence of either a coherent view of the appropriate interests to be served by such a policy or a strategy for resource utilization that reflects longterm goals and the capacity of the physical environment. In critiquing the World Conservation Strategy (IUCNNR, 1980), Daly (1980) and Tisdell (1983) pointed to the lack of any clear notion of whose interests conservation is serving or a cohesive view of time frame. These observations are equally valid for the North. Apart from Fuller and Hubert's (1981) work, there is scant discussion and no consensus regarding optimum resource consumption rates for present populations, what the desirable sustainable standard of living is and thus what the rate of future resource use should be. The promotion of forestry, agriculture and tourism appears to be divorced from any broad contextual considerations regarding their suitability as candidates for sustainability. Often it seems to be assumed that because an activity is nominally renewable or offers the possibility of substituting for imports it is sustainable. Such assumptions fail to consider the global impacts in terms of relative energy consumption or relative contribution to the deterioration of the global environment.

It is apparent that energy costs in terms of depletion of nonrenewable resources and contribution to global pollution are central to an evaluation of sustainability. Such considerations elevate the role of Native harvesting as a relatively conservationist approach to obtaining food, although demographic pressures may mean that in the long run it is not sustainable. They also point to the paradox between optimizing at the local level and optimizing for the globe that exists in regarding energy consumptive northern agriculture and tourism as sustainable activities. Modification of Weeden's (1989) basis for identification of sustainable activities, adding consideration of relative energy costs to the criteria of environmental compatibility, economic feasibility and social acceptability, would reduce the range of sustainable possibilities.

The relationship between the North and distant urban regions is, as Mulvihill and Jacobs (1991) argue, a key component of any rational approach to sustainable development. Urban regions, with their demands for industrial minerals and energy, have had a deleterious effect on the quality of the northern environment. At the local level this is manifest in visual degradation of landscapes, acidic leeching from tailing ponds (Duncan, 1975), modification of tundra landscapes in the quest for oil and natural gas, removal of vegetation cover (with subsequent eco-system modification) and disturbance and destruction of fish and wildlife habitats. Some pollutants found in the North, such as mercury (associated with activities as diverse as mining, pulp and paper processing and hydropower generation), emanate from urban-oriented industries located in the North, but others, especially airborne toxins, have their origin in industrial heartlands.

Many opponents of northern pipeline construction who made submissions to the Berger and Lysyk inquiries in the mid-1970s argued that the obvious approach to maintaining the quality of the northern environment lies in changing attitudes towards consumption and conservation in southern urban areas, that any amelioration of demands from urban areas will have a beneficial impact on the environment of the periphery. The traditional refutation of this approach has been that the heartland and the periphery are so interrelated that 
prosperity and the material quality of life in peripheral regions depend on urban output and that a portion of resource consumption is related to peripheral demands.

When the question of whether sustainable development in the North should be viewed as a relative (i.e., ameliorate the adverse impacts of development) or absolute (i.e., prohibit any type of development that has a negative impact on the environment) concept is considered, it becomes clear that the North and urban regions are bound by a Gordian knot. Which approach best reflects the axiom "think globally, act locally" is debatable. From a crude utilitarian standpoint, "the greatest happiness for the greatest number," the global perspective would be that some degradation of the northern environment in the course of energy extraction is acceptable if the result is reduction of global pollution. The local perspective that local landscapes, economies and social well-being would be adversely affected by such a course can be cast in other than selfish terms. Using community empowerment to prohibit activities that are not sustainable, that (in the case of unresolved Native claims) may be illegal, or that detract from the viability of local activities would promote global sustainability by forcing urban regions that demand energy and minerals from the North to conserve.

Problems can be anticipated with both approaches. Increased northern energy extraction would be futile if not accompanied by stringent long-term increases in efficiency and conservation in urban areas. On the other hand, prohibiting energy extraction in the North could merely exacerbate the global situation if the response of industrial societies was to turn to more highly polluting energy sources from elsewhere.

\section{CONCLUSIONS}

Although no single framework exists for the identification of potential sustainable activities, it is clear that there is some dissonance between types of activities viewed as sustainable and the true requirements of sustainability. It is suggested that relative energy consumption should be considered alongside social, conventional economic and environmental factors in identifying sustainable activities. At the local level the appropriateness of tourism and agriculture is questionable, while the value of Native harvesting as a relatively sustainable activity is cautiously endorsed, although the long-term prospects for this activity are debatable. Community-based agendas may not truly reflect the adage "think globally, act locally" and greater consideration has to be given to the appropriate and reciprocal relationship between the North and urban regions in global sustainable development strategies.

\section{REFERENCES}

ALASKAN AGRICULTURAL ACTION GROUP. 1983. An economic assessment of Alaskan agriculture. [Juneau?]: Division of Finance and Economics, Alaska. $186 \mathrm{p}$.

ASCH, M.J. 1982. Capital and economic development: A critical appraisal of the Mackenzie Valley Pipeline Commission. Culture 2(3):3-9.

BERKES, F. 1987. Common-property resource management and Cree Indian fisheries in subarctic Canada. In: McCay, B.M., and Acheson, J.M., eds. The question of the commons. Tucson: University of Arizona Press. 66-91.

BRIGHTMAN, R.A. 1987. Conservation and resource depletion: The case of the boreal forest Algonquians. In: McCay, B.M., and Acheson, J.M., eds. The question of the commons. Tucson: University of Arizona Press. 121-142.

BRODY, H. 1981. Maps and dreams. Vancouver: Douglas and McIntyre. 297 p.

CANADIAN GAS RESEARCH INSTITUTE. 1990. Natural gas and the environment. Toronto: Canadian Gas Association. 14 p.
CRUIKSHANK, J. 1974. Through the eyes of strangers. Whitehorse: Yukon Territorial Government. $118 \mathrm{p}$.

DALY, H.E. 1980. Economics, ecology and ethics: Essays towards a steady state economy. San Fransisco: Freeman. 372 p.

DIMITROV, P., and WEINSTEIN, M. 1984. So that the future will be ours. Unpubl. report prepared for Ross River Indian Band. 391 p. Available at Council for Yukon Indians, 18 Nisutlin Drive, Whitehorse, Yukon.

DUERDEN, F. 1983. Migration patterns and Yukon settlements 1968-78. Musk Ox 32:10-21.

1986. Teslin; Community and village economy. Unpubl. report prepared for Teslin Indian Band. 77 p. Available at the Economic Development Department, Council for Yukon Indians, Whitehorse, Yukon.

DUNCAN, D.W. 1975. Leachability of anvil ore, waste rock and tailings. Ottawa: Department of Indian Affairs and Northern Development, Arctic Land Use Research Program. 19 p.

FARB, P. 1968. Man's rise to civilization: As shown by the Indians of North America from primeval times to the coming of the industrial state. New York: Dutton. 294 p.

FIREY, W. 1966. Man, mind and the land; A theory of resource use. Glencoe, Illinois: Free Press. 256 p.

FULLER, S., and McTIERAN, T. 1987. Old Crow and the northern Yukon: Achieving sustainable renewable resource utilization. Alternatives 15(4):18-25.

FULLER, W.A., and HUBERT, B.A. 1981. Fish, fur and game in the NWT; Some problems of, and prospects for increased harvests, in renewable resources and the economy of the North. Ottawa: Association of Canadian Universities for Northern Studies. 12-29.

GOVERNMENT OF YUKON. 1986. Yukon 2000: Building the future. Whitehorse: Department of Economic Development.

HARDIN, G. 1968. The tragedy of the commons. Science 162:1243-1248.

HEARTWELL, C. 1988. The forest industry in the economy of the Yukon. Whitehorse: Department of Renewable Resources, Government of Yukon. $110 \mathrm{p}$.

HODGE, T. 1982. Energy in the Yukon: A soft path for a northern territory, Alternatives 10(4):3-12.

INTERNATIONAL UNION FOR THE CONSERVATION OF NATURE AND NATURAL RESOURCES (IUCNNR). 1980. World conservation strategy: Living resource conservation for sustainable development. Morges, Switzerland: United Nations Environment Program, World Wildlife Fund. $50 \mathrm{p}$.

KASSI, N. 1987. This land has sustained us. Alternatives 14(1):20-21.

LOVINS, A.B., LOVINS, H.L., and BENDER, M. 1984. Energy and agriculture. In: Jackson, W., Berry, W., and Colman, B., eds. Meeting the expectations of the land. San Francisco: Northpoint Press. 68-86.

MARTIN, C. 1978. Keepers of the game. Berkeley: University of California Press. 226 p.

McCANDLESS, R.G. 1985. Yukon wildlife; A social history. Edmonton: University of Alberta Press. 193 p.

MULVIHILL, P.R., and JACOBS, P. 1991. Towards new south/north development strategies in Canada. Alternatives 10(2):34-39.

NAESS, S. 1988. Sustainable development and the deep long range ecology movement. Trumpeter 5(4):138-152.

PELL, D., and WISMER, P. 1987. The role and limitations of community based economic development in Canada. Alternatives 14(1):31-34.

QUIGLEY, N.C., and McBRIDE, N.J. 1987. The structure of an arctic microeconomy; The traditional sector in community economic development. Arctic 40(3):204-210.

RAY, J.A. 1984. Periodic shortages, Native welfare and the Hudson's Bay Company 1670-1930. In: Krech, S., III, ed. The sub-arctic fur trade. Vancouver: University of British Columbia Press. 1-20.

REDPATH, D.K. 1979. Land use programs in Canada; Yukon Terrritory. Ottawa: Lands Directorate, Environment Canada. 303 p.

REES, W.E. 1988. Sustainable development: Economic myths and ecological realities. Trumpeter 5(4):133-188.

ROBINSON, J.L. 1945. Agriculture and forests of the Yukon Territory. Canadian Geographical Journal, August 1945:54-73.

ROBINSON, M., and PRETES, M. 1988. Beyond boom and bust: A strategy for sustainable development in the North. Polar Record 25(153):115-120.

ROSS, W.G. 1981. Whaling, Inuit and the Arctic Islands. In: Zaslow, M., ed. A century of Canada's Arctic Islands 1880-1980. Ottawa: Royal Geographic Society of Canada. 33-50.

RUSHFORTH, S. 1977. Country food. In: Watkins, M., ed. Dene Nation - The colony within. Toronto: University of Toronto Press. 32-47.

STAGER, J.K. 1974. Old Crow Y.T. and the proposed northern gas pipeline. Ottawa: Northern Pipeline Task Force on Northern Oil Development. Report No. 74-21. 
STAPLES, L. and USHER, P. 1988. Subsistence in the Yukon. Whitehorse: Council for Yukon Indians. $288 \mathrm{p}$.

STATISTICS CANADA. 1986. Human activity and the environment; A statistical compendium. Ottawa: Ministry of Supply and Services. $374 \mathrm{p}$.

STATISTICS CANADA. 1987. Census Bulletin 94-123. Ottawa: Ministry of Supply and Services. $103 \mathrm{p}$.

TASK FORCE TO REVIEW COMPREHENSIVE CLAIMS POLICY. 1985. Living treaties lasting agreements. Ottawa: Department of Indian Affairs and Northern Development. 132 p.

TISDELL, C.A. 1983. An economist's critique of the world conservation strategy, with examples from the Australian experience. Environmental Conservation 10(1):43-52.

USHER, P.J. 1971. The Bankslanders: Economy and ecology of a frontier trapping community. Vol. 2. Ottawa: Northern Science Research Group, Department of Indian Affairs and Northern Development. $169 \mathrm{p}$
1976. Evaluating country food in the northern Native economy. Arctic 29(2):105-120.

1987. Indigenous management systems and the conservation of wildlife in the Canadian North. Alternatives 14(1):3-9.

WEEDEN, R.B. 1985. Northern people, northern resources, and the dynamics of carrying capacity. Arctic 38(2):116-120.

1989. An exchange of sacred gifts. Thoughts toward sustainable development. Alternatives 16(1):42-49.

WOLFE, R.J., and WALKER, R.J. 1987. Subsistence economies in Alaska: Productivity, geography, and development impacts. Arctic Anthropology 24(2):56-81.

WORLD COMMISSION ON ENVIRONMENT AND DEVELOPMENT. 1987. Our common future: The report of the World Commission on Environment and Development. Oxford: Oxford University Press. 400 p. 